\title{
Extracellular carbonic anhydrases of the stromatolite-forming cyanobacterium Microcoleus chthonoplastes
}

\begin{abstract}
Correspondence
Natalia Pronina

pronina@ippras.ru
\end{abstract}

Received 30 October 2006

Revised 6 January 2007

Accepted 11 January 2007
Elena Kupriyanova, ${ }^{1}$ Arsenio Villarejo, ${ }^{2,3}$ Alexandra Markelova, ${ }^{1}$

Lyudmila Gerasimenko, ${ }^{4}$ Georgy Zavarzin, ${ }^{4}$ Göran Samuelsson, ${ }^{2}$

Dmitry A. Los ${ }^{1}$ and Natalia Pronina ${ }^{1}$

\author{
${ }^{1}$ Institute of Plant Physiology, Russian Academy of Sciences, Botanicheskaya Street 35, \\ Moscow, 127276 Russia \\ ${ }^{2}$ Umeå Plant Science Centre, Department of Plant Physiology, University of Umeå, S-901 87 \\ Umeå, Sweden \\ ${ }^{3}$ Department of Biology, Universidad Autonoma de Madrid, 28049 Madrid \\ ${ }^{4}$ Institute of Microbiology, Russian Academy of Sciences, Prospect 60-Letiya Oktyabrya 7/2, \\ Moscow, 117312 Russia
}

\begin{abstract}
Active extracellular carbonic anhydrases (CAs) were found in the alkaliphilic stromatolite-forming cyanobacterium Microcoleus chthonoplastes. Enzyme activity was detected in intact cells and in the cell envelope fraction. Western blot analysis of polypeptides from the cell envelope suggested the presence of at least two polypeptides cross-reacting with antibodies against both $\alpha$ and $\beta$ classes of CA. Immunocytochemical analysis revealed putative $\alpha$-CA localized in the glycocalyx. This $\alpha$-CA has a molecular mass of about $34 \mathrm{kDa}$ and a pl of 3.5. External CAs showed two peaks of activity at around $\mathrm{pH} 10$ and 7.5. The possible involvement of extracellular CAs of M. chthonoplastes in photosynthetic assimilation of inorganic carbon and its relationship to $\mathrm{CaCO}_{3}$ deposition during mineralization of cyanobacterial cells are discussed.
\end{abstract}

\section{INTRODUCTION}

The main features of the 'modern' biosphere were formed about 2 billion years ago, when prokaryotes dominated on Earth. The participation of cyanobacterial communities in deposition of atmospheric $\mathrm{CO}_{2}$ at early stages of the Earth's history have been confirmed by their presence in stromatolites. The latter represent layered limestone deposits that consist of lithified cyanobacterial communities, which are somewhat similar to modern benthic mats in terms of their morphology and ultrastructure (Sergeev et al., 2002). At the present point in geological time, stromatolite formation is rather insignificant, and the mechanisms of their formation are poorly known. It is still unclear whether mineralization occurs due to some metabolic processes in cyanobacteria, or whether the cyanobacteria just serve as a matrix for binding and structuring of carbonates in the natural process of calcium precipitation.

Carbonic anhydrase (CA, EC 4.2.1.1) is a zinc-containing enzyme catalysing a reversible hydration of carbon dioxide: $\mathrm{CO}_{2}+\mathrm{H}_{2} \mathrm{O} \leftrightarrow \mathrm{H}^{+}+\mathrm{HCO}_{3}^{-}$. CA operates with forms of

Abbreviations: $C A$, carbonic anhydrase; $C_{i}$, inorganic carbon; WAU, Wilbur-Anderson units. inorganic carbon $\left(\mathrm{C}_{\mathrm{i}}\right)$, including bicarbonate, which participate in calcium precipitation in nature. CAs have been found in all groups of living organisms. According to the accepted classification, CAs are divided into three main classes, $\alpha, \beta$ and $\gamma$, which have no significant primary sequence identity and, supposedly, are evolutionarily independent (Smith \& Ferry, 2000). The existence of additional $\delta$ and $\varepsilon$ classes of CAs have also been reported (Tripp et al., 2001; So et al., 2004).

Some eukaryotic algae are able to precipitate intracellular calcium carbonate due to the activity of intracellular CAs (Quiroga \& Gonzalez, 1993). In contrast, cyanobacteria can deposit calcium only outside the cells, and such precipitation is strictly controlled by $\mathrm{pH}$ (Zavarzin, 2002). It is likely that extracellular CAs of cyanobacterial cells might stabilize the pericellular $\mathrm{pH}$ and participate in cell mineralization. However, the cyanobacterial CAs of benthic communities have not been investigated so far.

It is well known that cyanobacterial communities are rather conserved and have not changed significantly during the past two billion years, in terms of their physiology and morphology. Thus, today's microbial communities can be used as a model system for the study of ancient 
mineralization. This is especially true for so-called 'relict' communities that are considered to be the analogues of ancient ecosystems. At present, such communities exist in extreme environments where no traces of higher organisms have been detected (Sergeev et al., 2002).

We studied CAs of the benthic cyanobacterium Microcoleus chthonoplastes. It dominates in alkaliphilic and halophilic cyanobacterial mats worldwide (Gerasimenko et al., 2003). The formation of calcium minerals on the outer mucous cover (glycocalyx) of this cyanobacterium has been reported both in natural samples in the mats (Gerasimenko et al., 2003) and also in laboratory culture (Zavarzin et al., 2003). We have identified extracellular CAs of $M$. chthonoplastes with access to outer $C_{i}$ substrates and indicated their possible participation in extracellular calcium carbonate precipitation.

\section{METHODS}

Strain and growth conditions. Microcoleus chthonoplastes was obtained from the Culture Collection of the Institute of Microbiology, Russian Academy of Sciences, Moscow, Russia, originally isolated from Khilganta soda lake (Buryatiya, Russia; $50^{\circ} 25^{\prime} \mathrm{N}$, $106^{\circ} 53^{\prime} \mathrm{E}$, altitude $606 \mathrm{~m}$ ) (Gerasimenko et al., 2003). The organism was grown in medium S (Castenholz \& Waterbury, 1989) (g l ${ }^{-1}: \mathrm{KCl}, 1.0 ; \mathrm{NaHCO}_{3}, 16.8 ; \mathrm{K}_{2} \mathrm{HPO}_{4}, 0.5 ; \mathrm{NaNO}_{3}, 2.5 ; \mathrm{K}_{2} \mathrm{SO}_{4}$, $1.0 ; \mathrm{NaCl}, 30 ; \mathrm{MgSO}_{4}, 0.1 ; \mathrm{CaCl}_{2}, 0.04 ; \mathrm{FeSO}_{4}, 0.01 ; \mathrm{EDTA}, 0.08, \mathrm{pH}$ 9.8) and micronutrients (Rippka et al., 1979) in batch cultures at $31{ }^{\circ} \mathrm{C}$ under continuous irradiance of $50 \mu \mathrm{mol} \mathrm{m}{ }^{-2} \mathrm{~s}^{-1}$ from cool white fluorescent lamps. All experiments were carried out with biomass after 4-5 days cultivation, corresponding to the midexponential phase of growth.

Isolation of cell envelopes and their fractions. Cells were broken in cooled buffer ( $30 \mathrm{mM}$ HEPES-KOH, pH 8.2) using a French press $\left(5 \times 10^{7} \mathrm{~Pa}\right)$. Unbroken cells were sedimented by centrifugation at $700 \mathrm{~g}$ for $10 \mathrm{~min}$ at $4{ }^{\circ} \mathrm{C}$. Cell envelopes of $M$. chthonoplastes were isolated by centrifugation of the cell homogenate at $12000 \mathrm{~g}$ according to Weckesser \& Jürgens (1988). To remove chlorophyll and soluble protein contaminations, the cell envelope fraction was washed four to five times with $30 \mathrm{mM}$ HEPES-KOH ( $\mathrm{pH}$ 8.2).

The isolation of cell walls and other components of the envelope was performed as described by Weckesser \& Jürgens (1988). The cell envelope fraction was loaded on a discontinuous sucrose gradient (60, $55,50,45$ and $40 \%$ sucrose in $30 \mathrm{mM}$ HEPES-KOH buffer, $\mathrm{pH} 8.2$ ) and centrifuged at 20000 r.p.m. in a Beckman SW 41 rotor for $4 \mathrm{~h}$ at $4{ }^{\circ} \mathrm{C}$. As a result, three main fractions were obtained: (1) two lower fractions of cell walls (at the bottom of the tube and at the 55/60\% sucrose interface); (2) a fraction of some cell envelope fragments at the $50 / 55 \%$ sucrose interface (supposedly glycocalyx); and (3) a lighter fraction of plasma membranes located above $40 \%$ sucrose. All these fractions were collected, and the two cell-wall fractions were combined. Traces of sucrose were removed by washing in $30 \mathrm{mM}$ HEPES-KOH buffer with centrifugation at $176000 \mathrm{~g}$ for $1 \mathrm{~h}$ at $4{ }^{\circ} \mathrm{C}$. Cell walls were further purified as described by Weckesser \& Jürgens (1988). During all isolation steps, protease inhibitor mix (Sigma) was added to avoid protein degradation.

Assay of CA activity. CA activity was measured electrometrically (Wilbur \& Anderson, 1948) by monitoring the rate of $\mathrm{pH}$ change during carbon dioxide hydration using a fast-response 'blue glass' microelectrode (MI-710; Microelectrodes) and an 18-bit A/D converter (IOtech). Measurements were performed with intact cells, cell homogenate and cell envelopes in $30 \mathrm{mM}$ HEPES-KOH buffer, $\mathrm{pH}$ 8.2. The reaction was carried out at $2{ }^{\circ} \mathrm{C}$ and started by a rapid injection of saturated $\mathrm{CO}_{2}$ solution into an equal volume of the sample (fermentative reaction) or buffer (non-fermentative reaction, control). The reaction kinetics were recorded for $100 \mathrm{~s}$. CA activity was calculated as the difference in the initial rate of $\mathrm{CO}_{2}$ hydration between control and samples, and expressed in Wilbur-Anderson units (WAU) per $1 \mathrm{mg}$ chlorophyll (Chl) or protein. One WAU is defined as $10 \times\left(t_{0}-t\right) t^{-1}$, where $t_{0}$ and $t$ are the times required for the $\mathrm{pH}$ to change by $\Delta \mathrm{pH}$ in the control and the samples, respectively. The measurements were carried out in three to five replicates.

To study the dependence of $M$. chthonoplastes extracellular CA activity on external $\mathrm{pH}$, the cyanobacterium was cultured at the optimum $\mathrm{pH}$ of 9.8 and then transferred to $\mathrm{S}$ medium at different $\mathrm{pH}$ values $(6.5,7.5$, 8.0, 9.0 and 9.8) and grown under similar culture conditions (light and temperature were not changed). CA activity in intact cells was measured after $1.5 \mathrm{~h}$ incubation. CA activity was expressed in relative units compared to the activity at the optimal $\mathrm{pH}$ of 9.8 .

Estimation of chlorophyll and protein content. Protein content was estimated in accordance with Bio-Rad Laboratories protocols using commercial kits with standard solutions (Bio-Rad DC Protein Assay Kit). Chlorophyll content was determined spectroscopically after extraction with absolute methanol (Porra et al., 1989).

Electrophoresis and immunodetection. Proteins were separated by 10 or $12 \%$ SDS-PAGE, following Laemmli (1970), or by twodimensional (2D) electrophoresis. A mix of protein standards (BioRad) was used as molecular mass markers.

For electrophoresis, a standard protocol and Bio-Rad buffers and solutions were used. The lanes were loaded with $15 \mu \mathrm{g}$ protein for silver-stained gels, and 20 or $45 \mu$ g protein for Coomassie-stained gels and immunoblot analysis, respectively. The samples were solubilized for $5 \mathrm{~min}$ at $95^{\circ} \mathrm{C}$ in the sample buffer.

2D electrophoresis was performed according to the manufacturer's instructions (Amersham). The protein content was $100 \mu \mathrm{g}$ for immunodetection or $300 \mu \mathrm{g}$ for silver-stained gels. Each sample was mixed with a rehydration solution containing $8 \mathrm{M}$ urea, $2 \%$ CHAPS, $20 \mathrm{mM}$ DTT, $0.5 \%$ IPG buffer (pH 3-10; Amersham) and $0.001 \%$ bromophenol blue. IPG dry strips (Immobiline DryStrip gels, $7 \mathrm{~cm}$, with a linear $\mathrm{pH}$ range coverage of 3-10; Amersham) were allowed to rehydrate in the presence of samples in the IPGphor Isoelectric Focusing System (Amersham), followed by isoelectric focusing of proteins at $20^{\circ} \mathrm{C}$. The following voltage/time profile was used: rehydration for $12 \mathrm{~h}$; increasing voltage by the 'step-and-hold' procedure from 500 to $1000 \mathrm{~V}$ over $1 \mathrm{~h}$; final phase of $8000 \mathrm{~V}$ for $12 \mathrm{~h}$. After the first dimension run, the individual strip was equilibrated for $15 \mathrm{~min}$ in SDS buffer $(50 \mathrm{mM}$ Tris/ $\mathrm{HCl}$, pH 6.8; $6 \mathrm{M}$ urea; $30 \%$, v/v, glycerol; $2 \%$ SDS) supplemented with $1 \%(\mathrm{w} / \mathrm{v})$ DTT, and then for another $15 \mathrm{~min}$ in SDS buffer supplemented with $2.5 \%(\mathrm{w} / \mathrm{v})$ iodoacetamide. Thereafter, the strips were put on the top of the second dimension gel (12\%) and covered with $0.5 \%$ agarose in SDS buffer. Each gel was run at $10 \mathrm{~mA}$ at the beginning and then at $15 \mathrm{~mA}$ per gel after all the proteins were transferred from the strip into the gel.

Immunoblotting was performed as described in the Bio-Rad Laboratories protocol. The primary antibodies were raised against: (1) Chlamydomonas reinhardtii $\alpha$-CA (Cah-3) (Karlsson et al., 1998) (affinity-purified); (2) C. reinhardtii mitochondrial $\beta$-CA (Eriksson et al., 1996); (3) spinach chloroplast $\beta$-CA (Fawcett et al., 1990); (4) Coccomyxa sp. intracellular $\beta$-CA (Hiltonen et al., 1998); and (5) C. reinhardtii D1 protein (PsbA) (Nishiyama et al., 2001). Horseradish 


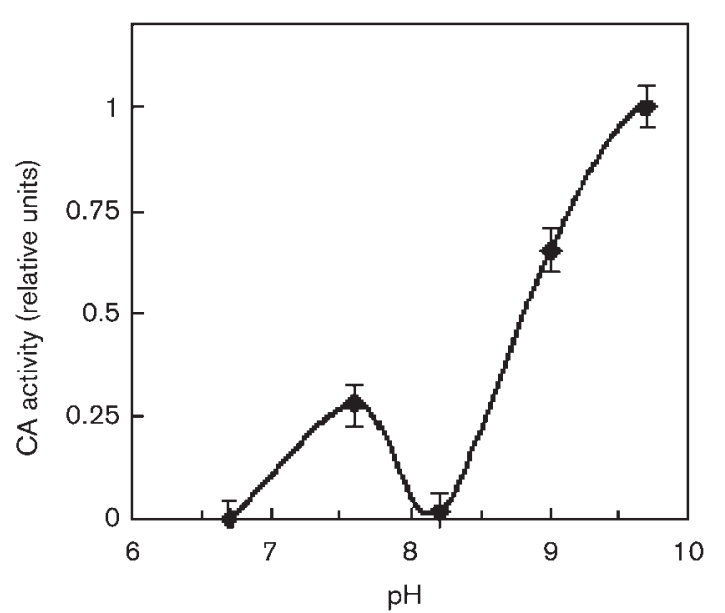

Fig. 1. $\mathrm{pH}$-dependence of extracellular $M$. chthonoplastes $\mathrm{CA}$ activity. Cyanobacterial cells were grown at the optimum $\mathrm{pH}$ of 9.8 and then transferred into $\mathrm{S}$ medium at different $\mathrm{pH}$ values $(6.5,7.5,8.0,9.0$ and 9.8). CA activity of intact cells was measured after incubation in these media for $1.5 \mathrm{~h}$. Since during the incubation the non-pH 9.8 culture media became more alkaline due to the buffering properties of medium $\mathrm{S}$, we have used the mean $\mathrm{pH}$ values in the figure. CA activity is expressed in relative units compared to the activity at the optimal $\mathrm{pH}$ of 9.8 .

peroxidase-labelled secondary antibodies (Amersham Life Science) and chemiluminescence solutions (ECL, Amersham) were used to detect an antibody-antigen conjugate.

Immunoelectron microscopy. For immunogold labelling experiments, M. chthonoplastes cells or the isolated fraction of glycocalyx were fixed in $4 \%$ paraformaldehyde for $4-10$ days at $4{ }^{\circ} \mathrm{C}$. Immunocytochemical reactions were performed after washing the sample in $0.1 \mathrm{M}$ phosphate buffer $(\mathrm{pH}$ 7.4). The reaction with primary antibodies against $C$. reinhardtii $\alpha$-CA (Cah-3) was carried out for $1 \mathrm{~h}$ at $24^{\circ} \mathrm{C}$ and then for $23 \mathrm{~h}$ at $4{ }^{\circ} \mathrm{C}$. Thereafter, the samples were washed three times with phosphate buffer over a $24 \mathrm{~h}$ period. The second step of the immunochemical reaction and post-washing were performed under similar conditions using Protein-A-Gold (Sigma). The samples were post-fixed in $1 \% \mathrm{OsO}_{4}$, dehydrated in an alcohol series and embedded in Epoxy resin (Sigma). As a control for immunochemical reaction specificity, the sample treatment step with primary antibodies was omitted. Thin sections of samples were prepared using an ultramicrotome and then analysed with a JEM JEOL X-100 transmission electron microscope (Japan) without any additional contrast.

\section{RESULTS}

\section{Activity of M. chthonoplastes extracellular CA}

CA activity was detected both in the intact cells $[0.238 \pm 0.01$ WAU (mg protein $)^{-1}, 24 \pm 4$ WAU (mg chlorophyll $)^{-1}$ ] and in the cell envelope fraction $[0.318 \pm 0.01$ WAU (mg protein $)^{-1}$ ] of $M$. chthonoplastes (mean values from three independent experiments). Thus, in spite of some possible CA inactivation during the isolation of cell envelopes, the results showed enrichment of CA activity in the cell envelope fraction compared to intact cells. CA activity was not detected in the cell homogenate. This could be due to (1) low enzyme activity as a result of inhibition by compounds in the homogenate, or (2) low CA content relative to the total protein content of the fraction.

The highest activity of $M$. chthonoplastes extracellular CA was detected in intact cells incubated at an alkaline $\mathrm{pH}$ $(\sim 10)$ which is optimal for the growth of this alkaliphilic cyanobacterium. Enzyme activity was also recorded at a near neutral $\mathrm{pH}(\sim 7.5)$ (Fig. 1). There was no detectable CA activity in intact cells incubated at pH 6.7 and 8.2.

\section{Identification of $M$. chthonoplastes extracellular $\alpha$-CA}

To identify the protein responsible for this enzyme activity, Western blotting of the fractions with antibodies raised against C. reinhardtii $\alpha$-CA (Cah-3) was carried out. These antibodies cross-reacted with only one specific protein of approximately $34 \mathrm{kDa}$ (Fig. 2b). The protein cross-reacting with the Cah3 antibodies was clearly enriched in the cell

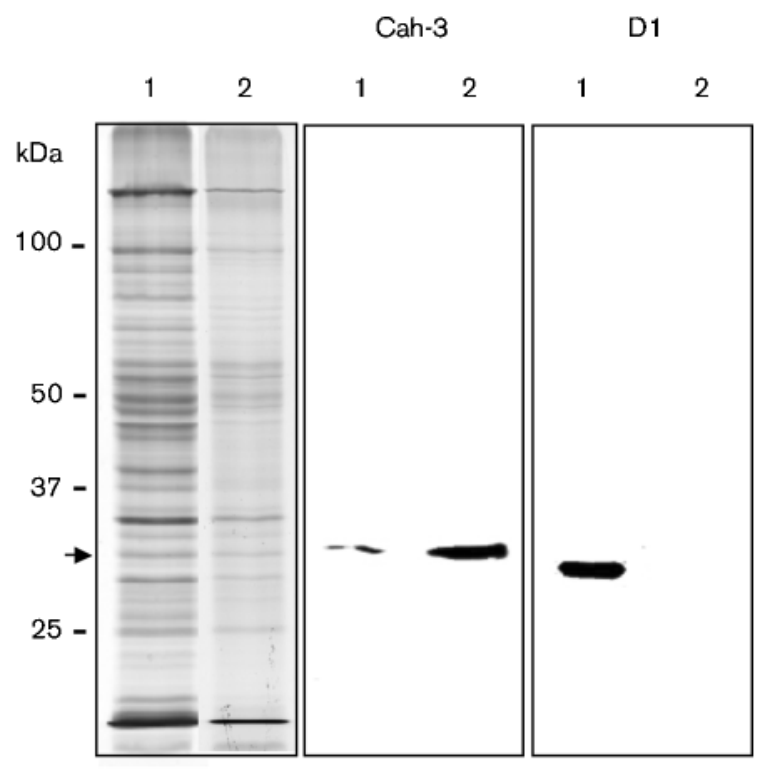

(a)

(b)

(c)

Fig. 2. Identification of $M$. chthonoplastes extracellular $\alpha$-CA. (a) SDS-PAGE (10\%) analysis of the polypeptide composition of $M$. chthonoplastes cell homogenate and cell envelope fraction. The gel was stained with Coomassie brilliant blue R-250. (b) Immunodetection of $\alpha$-CA in cell envelopes of $M$. chthonoplastes. The blot was probed with antibodies raised against $C$. reinhardtii $\alpha$-CA (Cah-3). (c) Immunoblot with antibodies against the D1 (PsbA) protein (test for cross-contamination of M. chthonoplastes cell envelopes with thylakoid membranes). Lanes: 1, cell homogenate; 2, isolated cell envelopes. The lanes contained 20 and $45 \mu \mathrm{g}$ protein for the Coomassiestained gel and for immunoblotting, respectively. The arrow indicates the position of the Cah-3-like protein in the gel. 
envelope fraction when compared to the cell homogenate (Fig. 2b). This enrichment corresponded with the higher enzyme activity seen in the cell envelope fraction (see above).

As Cah-3 is known to be associated with polypeptides of photosystem (PS) II of C. reinhardtii thylakoid membranes (Park et al., 1999; Villarejo et al., 2002), it was necessary to be sure that the signal observed in the cell envelope fraction of M. chthonoplastes did not result from cross-contamination of this fraction with thylakoid membranes from the cyanobacterium. Antibodies against D1 (PsbA), a major protein of PS II, was used as a specific marker for thylakoid membranes (Nishiyama et al., 2001). Fig. 2(c) shows that cell envelopes did not cross-react with these antibodies, which implies the absence of thylakoid membrane contamination in this fraction.

\section{Immunocytochemical detection of $\alpha$-CA}

Localization of $\alpha$-CA in $M$. chthonoplastes cells was also investigated by immunogold electron microscopy using antibodies against C. reinhardtii $\alpha$-CA (Cah-3) (Fig. 3). The electron-impermeable spots of colloidal gold are clearly visible in the glycocalyx (Fig. 3b). This structure and analogous specific signals are also typical of the fragments located at the interface between 50 and $55 \%$ sucrose during cell envelope fractionation (Fig. 3d). Thus, one can conclude that this fraction consists of glycocalyx.
It is known that the cell envelopes of cyanobacteria have a quite complex structure and are composed of the outer membrane with glycocalyx, a peptidoglycan layer and a plasma membrane (Gantt, 1994). Our attempts to detect CA activity in different fractions obtained after further fractionation of the cell envelopes from $M$. chthonoplastes failed. Apparently, in spite of the presence of protease inhibitors, enzyme activity decreased drastically during fractionation. However, the presence of a potential $\alpha$-CA in these fractions was tested by Western blot analysis with antibodies against $C$. reinhardtii $\alpha$-CA (Cah-3). Fig. 4 shows that the signal was specifically enriched in a fraction characterized as glycocalyx, but there was no signal in the cell wall or plasma membrane fractions. It thus appears that the specific signal observed in the cell envelopes (Fig. 2b) was due to the presence of a Cah-3-like enzyme in the $M$. chthonoplastes glycocalyx.

\section{Analysis of $M$. chthonoplastes glycocalyx protein composition by 2D electrophoresis}

2D electrophoresis followed by Western blotting with antibodies against $C$. reinhardtii $\alpha$-CA (Cah-3) enabled us to estimate the protein composition of the M. chthonoplastes glycocalyx fraction as well as the isoelectric point of extracellular $\alpha$-CA (Fig. 5). The analysis of the silver-stained 2D gel showed the presence of approximately 15-20 various polypeptides in the M. chthonoplastes glycocalyx. Practically all the proteins in this fraction were acidic, with pI values
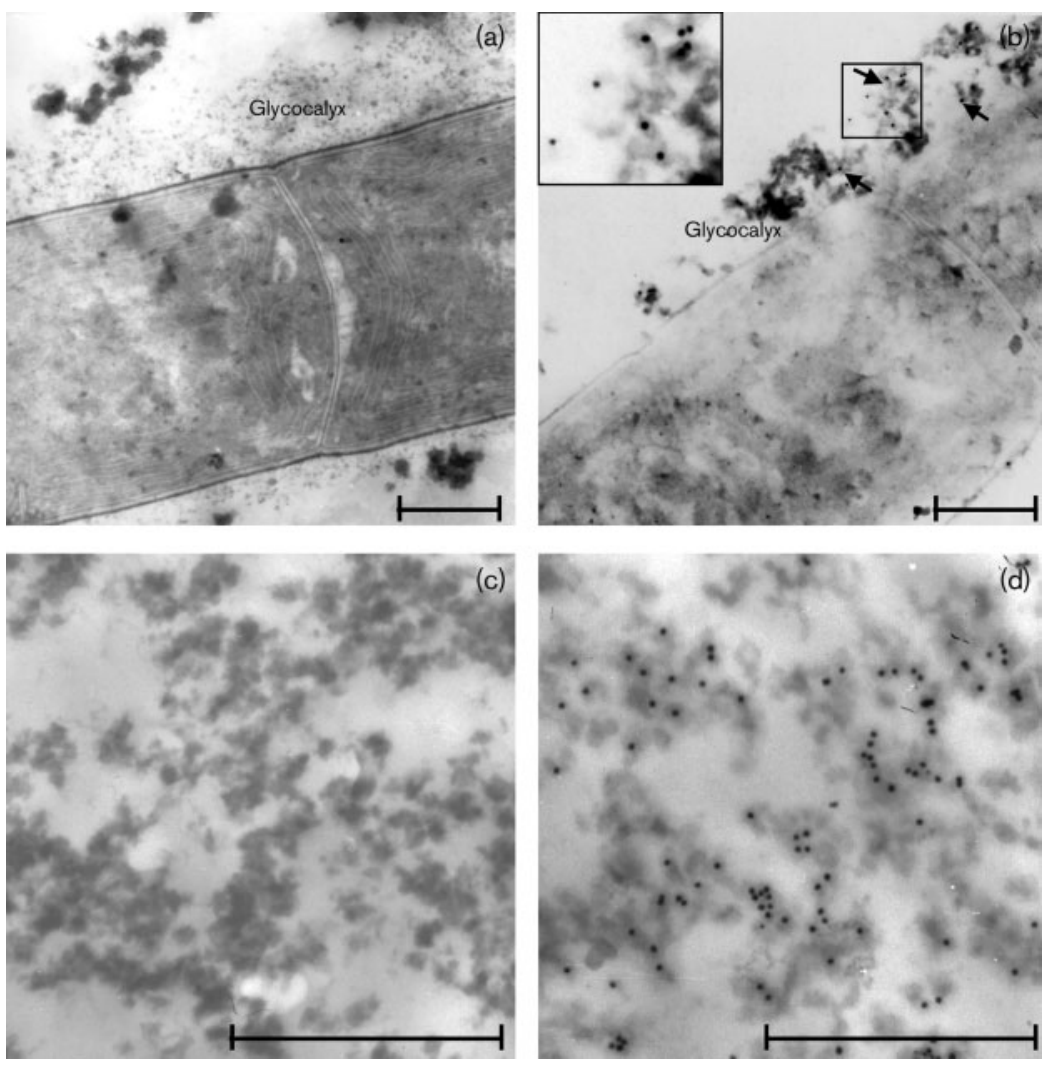

Fig. 3. Immunocytochemical localization of $\alpha-\mathrm{CA}$ in $M$. chthonoplastes cells and isolated glycocalyx (The glycocalyx is the fraction isolated from the interface between 50 and $55 \%$ sucrose during the cell envelope fractionation.). ( $\mathrm{a}, \mathrm{b})$ Thin sections of $M$. chthonoplastes cell (control and experimental sample, respectively). Gold particles localized in the glycocalyx are shown in the enlarged inset in the top left of panel (b). (c, d) Isolated glycocalyx from $M$. chthonoplastes (control and experimental sample, respectively). For the immunocytochemical reaction, antibodies against $C$. reinhardtii $\alpha-C A$ (Cah-3) and Protein-A-Gold (Sigma) were used. The arrows indicate the localization of $\alpha$ CA. Bars, $1 \mu \mathrm{m}$. 


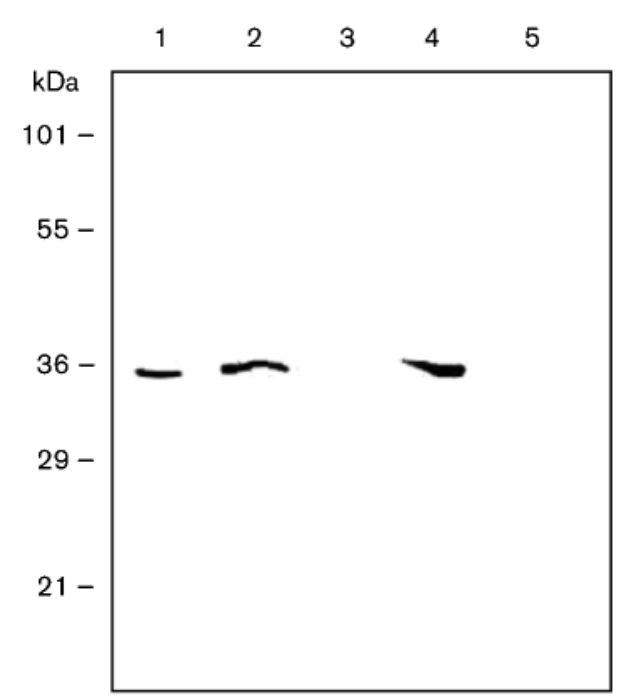

Fig. 4. Immunodetection of $\alpha-C A$ in $M$. chthonoplastes cell envelope fractions following SDS-PAGE (12\%). The blot was probed with antibodies against $C$. reinhardtii $\alpha-C A$ (Cah-3). Lanes: 1, cell homogenate; 2, cell envelopes; 3, cell walls; 4, glycocalyx; 5, plasma membranes. All lanes contained $45 \mu \mathrm{g}$ protein.

ranging from 3 to 5 , as has been reported in other cyanobacteria (Huang et al., 2004). However, the most abundant protein of this fraction was basic, with an estimated pI value of 9.5 and a approximate molecular mass of $18 \mathrm{kDa}$.

Immunoblotting showed that the Cah-3-like protein, which was recognized by the antibodies, was located in a region of low pI (about 3.5). The molecular mass of this protein was about $34 \mathrm{kDa}$, i.e. similar to that of Cah-3-like protein observed in 1D electrophoresis analysis.

\section{Identification of $M$. chthonoplastes extracellular $\beta$-CAs}

For identification of $\beta$-CAs among $M$. chthonoplastes cell envelope proteins, primary antibodies against $\beta$-CAs from various organisms were used, i.e. spinach chloroplasts and C. reinhardtii mitochondria, as well as antibodies against intracellular $\beta$-CA from the photobiont microalga Coccomyxa sp. This decision to use several types of antibody was determined by the multiplicity of the $\beta$-CA isoforms.

The cross-reaction between the M. chthonoplastes cell envelope polypeptides and the antibodies against spinach and $C$. reinhardtii $\beta$-CAs revealed the presence of several specific signals (Fig. 6). These signals were much stronger than those of the cell homogenate. The molecular masses of polypeptides detected by different antibodies were not identical. No cross-reaction was detected by Western blotting when the antibodies against the intracellular CA of Coccomyxa sp. was probed (not shown).

\section{DISCUSSION}

CA activity detected in intact cells as well as in the cell envelopes of $M$. chthonoplastes indicates that the cyanobacterium possesses extracellular enzyme(s), which can use external $\mathrm{C}_{\mathrm{i}}$ as a substrate. Western blot analysis has suggested a multiplicity of potential extracellular CAs related to either the $\alpha$ - or $\beta$-classes.

Until now, the presence of external $\alpha$-CA (possibly periplasmic) had been shown in only two species of cyanobacteria, Anabaena sp. PCC 7120 and Synechococcus sp. PCC 7942. However, enzyme activity of the identified $\alpha$-CA (EcaA) was not detected either in whole-cell lysates or in cell fractions of these cyanobacteria (SoltesRak et al., 1997). It was postulated that the cause of this failure could be due to the low sensitivity of the electrometrical method used for CA activity measurement. Extracellular localization in the periplasmic space was also assumed for EcaB ( $\beta$-CA) of Synechocystis PCC 6803 (So et al., 1998).

The levels of $M$. chthonoplastes extracellular CA activity detected are comparable with enzyme activities of some other prokaryotic CAs, for example the intracellular enzyme activity of Anabaena variabilis (Yagawa et al., 1984), as well as with the activities of CAs from microalgal chloroplasts (a)

3

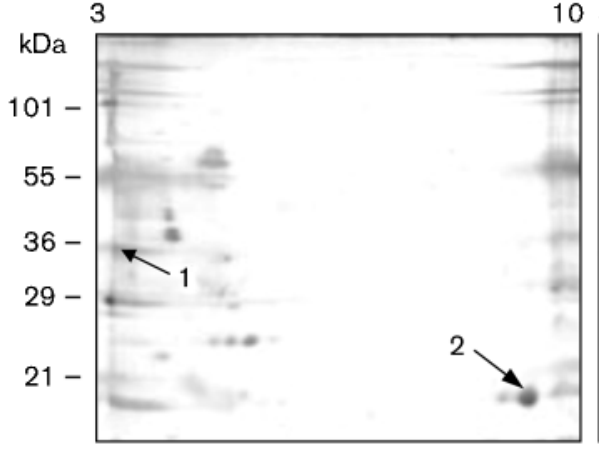

(b)

103

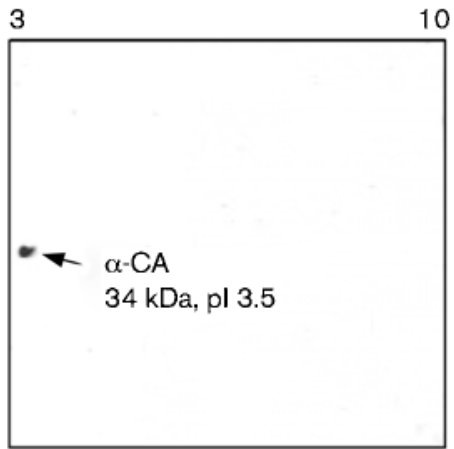

Fig. 5. 2D electrophoresis (a) and Western blot analysis (b) of the glycocalyx fraction from $M$. chthonoplastes. The silver-stained gel and gel for immunodetection were loaded with 300 and $100 \mu \mathrm{g}$ protein, respectively. The blot was probed with antibodies directed against $C$. reinhardtii $\alpha-C A$ (Cah-3). 1, Localization of Cah-3-like protein in the gel; 2 , localization of the major protein in the glycocalyx fraction. 
(a)

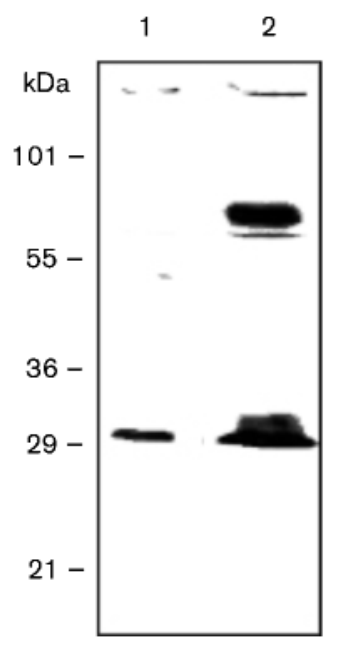

(b)

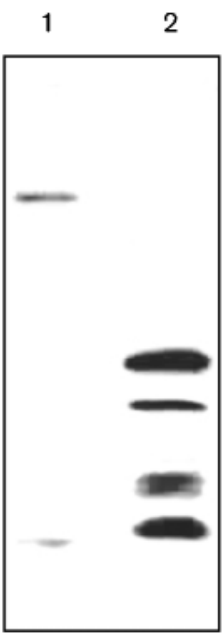

Fig. 6. Identification of $M$. chthonoplastes extracellular $\beta$-CAs using immunoblot analysis with antibodies raised against various $\beta$-CAs following SDS-PAGE (12\%). (a) Antibodies against mitochondrial $\beta$-CA from $C$. reinhardtii. (b) Antibodies against $\beta$-CA from spinach chloroplasts. Lanes: 1 , cell homogenate; 2 , isolated cell envelopes. Lanes were loaded with $45 \mu \mathrm{g}$ protein.

(Katzman et al., 1994). In addition to a potential $\alpha$-class enzyme, at least two putative $\beta$-CAs were found in the cell envelopes of $M$. chthonoplastes: one of them is similar to chloroplastic $\beta$-CAs and the other to mitochondrial $\beta$-CAs (Fig. 6). Numerous other specific signals probably resulted from incomplete denaturation of native $\beta$-CAs consisting of several subunits (Smith \& Ferry, 2000). The exact topology of these extracellular $\beta$-CAs within cell envelopes of $M$. chthonoplastes is still not clear.

Studies of the CAs of alkaliphilic cyanobacteria from soda lakes are important with respect to evolutional theory, because these organisms are supposed to be relicts of ancient microbiota (Sergeev et al., 2002). Genome analysis of many prokaryotic organisms has revealed the prevalence of $\beta$ - and $\gamma$-CAs, which have been proposed to be the most ancient classes of CAs (Smith \& Ferry, 2000). It has been assumed that $\alpha$-CAs evolved from a common ancestral gene about $0.5-0.6$ billion years ago (Smith \& Ferry, 2000). This is consistent with the evidence that only a few prokaryotic genomes encode $\alpha$-class enzymes. However, $\alpha$-CAs have been found in some bacteria (Nafi et al., 1990; Chirica et al., 1997) and cyanobacteria (Soltes-Rak et al., 1997; Dudoladova et al., 2004) where they have been characterized as extracellular enzymes, similar to the $\alpha$-CA of $M$. chthonoplastes. Thus, the presence of this class of CAs in relict organisms, as well as in other bacteria, indicates that $\alpha$-CAs are as ancient as $\beta$ - and $\gamma$-CAs.

The participation of CAs in the autotrophic assimilation of $C_{i}$ by cyanobacteria is well known. It is supposed that the function of extracellular forms of the enzyme $(\alpha-\mathrm{EcaA}$ and $\beta-\mathrm{EcaB})$ is associated with $\mathrm{C}_{\mathrm{i}}$ transport from the medium into the cell by $\mathrm{CO}_{2}$ and/or $\mathrm{HCO}_{3}^{-}$substrate formation for carbon transporters located in the plasma membrane. For intracellular $\beta$-CAs (IcfA and CcaA), which are located in the carboxysome, a role in $\mathrm{CO}_{2}$ generation is

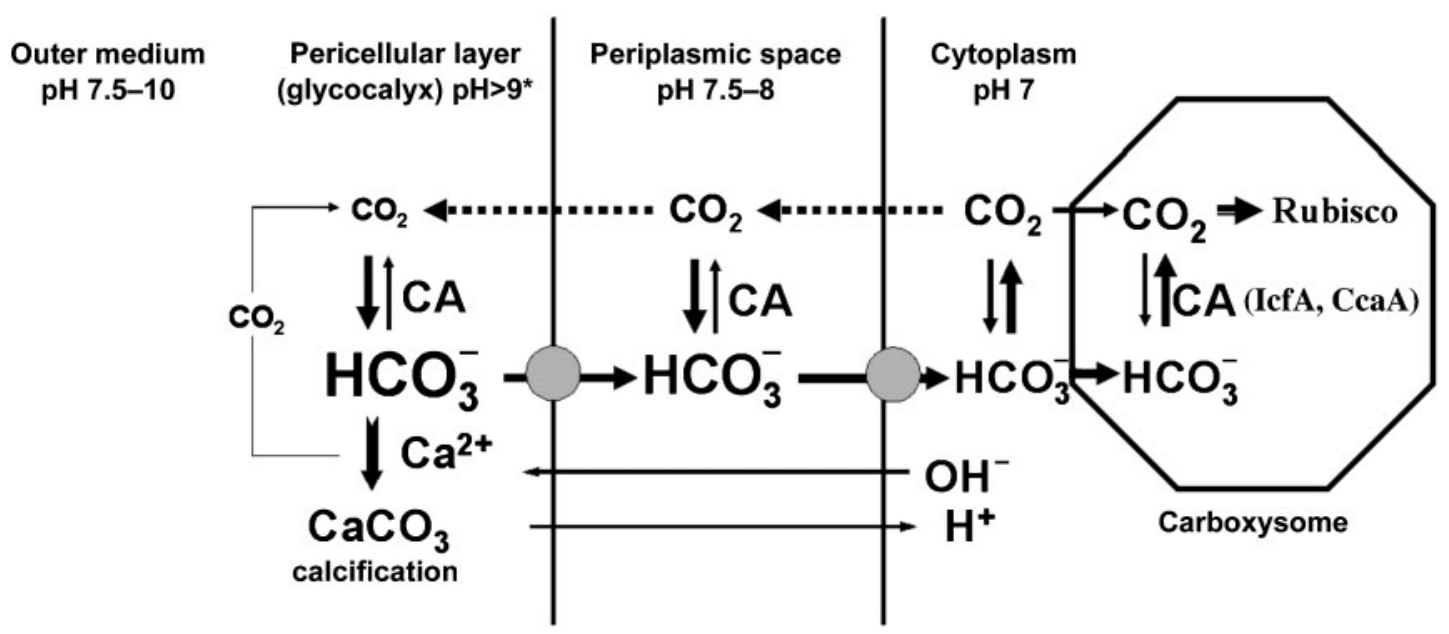

Fig. 7. A hypothetical scheme showing the role of $M$. chthonoplastes extracellular $C A s$ in $C_{i}$ assimilation and its connection with calcium carbonate deposition outside the cell. The size of the type is proportional to the $C_{i}$ concentration in the medium and cell compartments. The localization of the carboxisomal CAs (IcfA and CcaA) is as described by Smith \& Ferry (2000). An outer alkaline $\mathrm{pH}$ of about 10 corresponds to the soda lake environment whereas an outer $\mathrm{pH}$ of about 7.5 corresponds to conditions where $\mathrm{CaCO}_{3}$ deposition in cyanobacterial mats usually occurs (seashore conditions where oceanic water is mixed with continental river waters.) *Alkalinization of the pericellular layer as a result of $C_{i}$ assimilation is only relevant when the outer medium $\mathrm{pH}$ approaches neutral. 
presumed in the place of the fixing of $\mathrm{CO}_{2}$ by Rubisco (Smith \& Ferry, 2000).

A general scheme of extracellular CA participation in $\mathrm{C}_{\mathrm{i}}$ assimilation of M. chthonoplastes is presented in Fig. 7. In soda lakes, where the $\mathrm{pH}$ is highly alkaline (near 10), all dissolved $\mathrm{C}_{\mathrm{i}}$ is present as carbonate and bicarbonate ions. In cyanobacterial cells, the existence of several $\mathrm{HCO}_{3}^{-}$transport systems has been demonstrated (Badger \& Price, 2003). The majority of bicarbonate ions absorbed by the cell enter the carboxysome where they are converted to $\mathrm{CO}_{2}$ by intracellular $\beta$-CAs, which is then fixed by Rubisco. Some of the absorbed $\mathrm{HCO}_{3}^{-}$can also be converted into $\mathrm{CO}_{2}$ before being fixed by photosynthesis in accordance with the Henderson-Hasselbalch equation because of the lower intracellular $\mathrm{pH}$ compared to that of the outer medium. It has been shown previously that the cytoplasmic $\mathrm{pH}$ of alkaliphilic cyanobacteria is neutral (Kupriyanova et al., 2003). According to the concentration gradient, there must be some leakage of the $\mathrm{CO}_{2}$ produced in the intracellular space out of the cell. However, $\alpha$ - and $\beta$-CAs, which are located in the cell envelope of cyanobacteria, might prevent this leakage of $\mathrm{CO}_{2}$ by converting it to $\mathrm{HCO}_{3}^{-}$. This is then transported through the membrane back into the cell by carbon transporters. This is in accordance with high enzyme activity of extracellular CA observed under alkaline $\mathrm{pH}$ conditions (Fig. 1) typical of the natural habitat of $M$. chthonoplastes in soda lakes.

The second peak of extracellular enzyme activity at $\mathrm{pH}$ near 7.5 (Fig. 1) reflects the ability of $M$. chthonoplastes to live in the seashore environment with a $\mathrm{pH}$ close to this value. The mineralization of cyanobacteria usually occurs under such conditions because seawater has a large reserve of $\mathrm{Ca}^{2+}$ ions (Zavarzin et al., 2003). Stromatolite formation does not occur in soda lakes because calcium ions almost disappear from the medium at high $\mathrm{pH}$, having been precipitated as $\mathrm{CaCO}_{3}$.

The mechanisms of bicarbonate uptake discovered in cyanobacterial cells are associated solely with the alkalinization of the pericellular space. Bicarbonate assimilation could be accompanied by hydroxyl excretion into the outer medium (McConnaughey, 1994) and/or by sodium symport (Badger \& Price, 2003). The latter mechanism leads to alkalinization of cytoplasm followed by activation of $\mathrm{Na}^{+}$ATPase that assists $\mathrm{Na}^{+}$exchange for $\mathrm{H}^{+}$from the outer medium (Balnokin et al., 2004). These mechanisms are shown schematically in Fig. 7.

When the $\mathrm{pH}$ of the pericellular layers rises to 9.0 , calcium carbonate granules are produced in the cyanobacterial glycocalyx if free $\mathrm{Ca}^{2+}$ is available in the medium. The glycocalyx facilitates mineralization because it helps in the formation of a physicochemical/chemical microgradient by decreasing the rate of diffusion flow, and it binds divalent cations, including $\mathrm{Ca}^{2+}$, from the external medium due to the presence of polysaccharide carboxyl groups (Arp et al., 2001). Thus, photosynthetic assimilation of $C_{\mathrm{i}}$ by $M$. chthonoplastes cells appears to be accompanied by their mineralization under $\mathrm{pH}$ conditions found in seawater. CAs possibly stabilize $\mathrm{pH}$ in the pericellular space and maintain the substrate $\left(\mathrm{HCO}_{3}^{-}\right)$concentration essential for both photosynthesis and $\mathrm{CaCO}_{3}$ deposition.

\section{ACKNOWLEDGEMENTS}

We are grateful to Dr M. Eriksson (Umeå University, Sweden) who kindly provided antibodies against mitochondrial CA from $C$. reinhardtii. We thank Dr N. L. Klyachko (Institute of Plant Physiology, Russia) for helpful discussions and her advice at the stage of preparation of the manuscript. The work was supported by grants from European Molecular Biology Organization (EMBO Short-term Fellowship ASTF 12-02) and from the Ministry of Science and Education (MK-3393.2005.4) to E.K., grants from the Russian Foundation for Basic Research (04-04-49407 and 05-04-50883) to N.P. and D. A.L., grants from the 'Molecular and Cell Biology Program' and 'Evolution of Biosphere Program' of the Russian Academy of Sciences to D. A. L and G. Z., and a grant from the Swedish Foundation for International Cooperation in Research and Higher Education (STINT) to G.S.

\section{REFERENCES}

Arp, G., Reimer, A. \& Reitner, J. (2001). Photosynthesis-induced biofilm calcification and calcium concentrations in phanerozoic oceans. Science 292, 1701-1704.

Badger, M. R. \& Price, G. D. (2003). $\mathrm{CO}_{2}$ concentrating mechanisms in cyanobacteria: molecular components, their diversity and evolution. J Exp Bot 54, 609-622.

Balnokin, Y. V., Popova, L. G., Pagis, L. Y. \& Andreev, I. M. (2004). The $\mathrm{Na}^{+}$-translocating ATPase in the plasma membrane of the marine microalga Tetraselmis viridis catalyzes $\mathrm{Na}^{+} / \mathrm{H}^{+}$exchange. Planta 219, 332-337.

Castenholz, R. W. \& Waterbury, J. B. (1989). Group I. Cyanobacteria. In Bergey's Manual of Systematic Bacteriology, vol. 3, pp. 1710-1727. Edited by J. T. Staley, M. P. Bryant, N. Pfennig \& J. G. Holt. Baltimore, MD: Williams \& Wilkins.

Chirica, L. C., Elleby, B., Jonsson, B. H. \& Lindskog, S. (1997). The complete sequence, expression in Escherichia coli, purification and some properties of carbonic anhydrase from Neisseria gonorrhoeae. Eur J Biochem 244, 755-760.

Dudoladova, M. V., Markelova, A. G., Lebedeva, N. V. \& Pronina, N. A. (2004). Compartmentation of $\alpha$ - and $\beta$-carbonic anhydrases in the cells of halo- and alkaliphilic cyanobacterium Rhabdoderma lineare. Russ J Plant Physiol 51, 806-814.

Eriksson, M., Karlsson, J., Ramazanov, Z., Gardestrom, P. \& Samuelsson, G. (1996). Discovery of an algal mitochondrial carbonic anhydrase: molecular cloning and characterisation of a low$\mathrm{CO}_{2}$-induced polypeptide in Chlamydomonas reinhardtii. Proc Natl Acad Sci U S A 93, 12031-12034.

Fawcett, T. W., Browse, J. A., Volokita, M. \& Bartlett, S. G. (1990). Spinach carbonic anhydrase primary structure deduced from the sequence of a cDNA clone. J Biol Chem 265, 5414-5417.

Gantt, E. (1994). Supermolecular membrane organization. In The Molecular Biology of Cyanobacteria, pp. 119-138. Edited by D. A. Bryant. Dordrecht: Kluwer. 
Gerasimenko, L. M., Mityushina, L. L. \& Namsaraev, B. B. (2003). Microcoleus mats from alkaliphilic and halophilic communities. Mikrobiologiia 72, 71-79.

Hiltonen, T., Bjorkbacka, H., Forsman, C., Clarke, A. K. \& Samuelsson, G. (1998). Intracellular $\beta$-carbonic anhydrase of the unicellular green alga Coccomyxa. Cloning of the cDNA and characterization of the functional enzyme overexpressed in Escherichia coli. Plant Physiol 117, 1341-1349.

Huang, F., Hedman, E., Funk, C., Kieselbach, T., Schroder, W. P. \& Norling, B. (2004). Isolation of outer membrane of Synechocystis sp. PCC 6803 and its proteomic characterization. Mol Cell Proteomics 3, 586-595.

Karlsson, J., Clarke, A. K., Chen, Z. Y., Hugghins, S. Y., Park, Y.-I., Husic, H. D., Moroney, J. V. \& Samuelsson, G. (1998). A novel alpha-type carbonic anhydrase associated with the thylakoid membrane in Chlamydomonas reinhardtii is required at ambient $\mathrm{CO}_{2}$. EMBO J 17, 1208-1216.

Katzman, G. L., Carlson, S. J., Marcus, Y., Moroney, J. V. \& Togasaki, R. K. (1994). Carbonic anhydrase activity in isolated chloroplasts of wild-type and high- $\mathrm{CO}_{2}$-dependent mutants of Chlamydomonas reinhardtii as studied by a new assay. Plant Physiol 105, 1197-1202.

Kupriyanova, E. V., Lebedeva, N. V., Dudoladova, M. V., Gerasimenko, L. M., Alekseeva, S. G., Pronina, N. A. \& Zavarzin, G. A. (2003). Carbonic anhydrase activity of alkaliphilic cyanobacteria from soda lakes. Russ J Plant Physiol 50, 532-539.

Laemmli, U. K. (1970). Cleavage of structural proteins during the assembly of the head of bacteriophage T4. Nature 227, 680-685.

McConnaughey, T. A. (1994). Calcification, photosynthesis and global carbon cycles. Bull Inst Oceanogr 13, 137-161.

Nafi, B. M., Miles, R. J., Butler, L. O., Carter, N. D., Kelly, C. \& Jeffery, S. (1990). Expression of carbonic anhydrase in neisseriae and other heterotrophic bacteria. J Med Microbiol 32, 1-7.

Nishiyama, Y., Yamamoto, H., Allakhverdiev, S. I., Inaba, M., Yokota, A. \& Murata, N. (2001). Oxidative stress inhibits the repair of photodamage to the photosynthetic machinery. EMBO J 20, 5587-5594.

Park, Y.-I., Karlsson, J., Rojdestvenski, I., Pronina, N., Klimov, V., Oquist, G. \& Samuelsson, G. (1999). Role of a novel photosystem II-associated carbonic anhydrase in photosynthetic carbon assimilation in Chlamydomonas reinhardtii. FEBS Lett 444, 102-105.

Porra, R. J., Thompson, W. A. \& Kriedemann, P. E. (1989). Determination of accurate extinction coefficients and simultaneous equations for assaying chlorophylls a and $\mathrm{b}$ extracted with four different solvents: verification of the concentrations of chlorophyll standards by absorption spectroscopy. Biochim Biophys Acta 975, 384-394.
Quiroga, O. \& Gonzalez, E. L. (1993). Carbonic anhydrase in the chloroplast of a coccolithophorid (Prymnesiophyceae). J Phycol 29, 321-324.

Rippka, R., DeReuelles, J., Waterbury, J. B., Herdman, M. \& Stanier, R. Y. (1979). Generic assignments, strain histories and properties of pure cultures of cyanobacteria. J Gen Microbiol 111, 1-61.

Sergeev, V. N., Gerasimenko, L. M. \& Zavarzin, G. A. (2002). The proterozoic history and present state of cyanobacteria. Mikrobiologiia 71, 623-637.

Smith, K. S. \& Ferry, J. G. (2000). Prokaryotic carbonic anhydrases. FEMS Microbiol Rev 24, 335-366.

So, A. K., Van Spall, H. G. C., Coleman, J. R. \& Espie, O. S. (1998). Catalytic exchange of ${ }^{18} \mathrm{O}$ from ${ }^{13} \mathrm{C}^{18} \mathrm{O}$-labelled $\mathrm{CO}_{2}$ by wild type cells and ecaA, ecaB, and $c c a A$ mutants of the cyanobacteria Synechococcus PCC 7942 and Synechocystis PCC 6803. Can J Bot 76, 1153-1160.

So, A. K., Espie, G. S., Williams, E. B., Shively, J. M., Heinhorst, S. \& Cannon, G. C. (2004). A novel evolutionary lineage of carbonic anhydrase (epsilon class) is a component of the carboxysome shell. J Bacteriol 186, 623-630.

Soltes-Rak, E., Mulligan, M. E. \& Coleman, J. R. (1997). Identification and characterization of gene encoding a vertebratetype carbonic anhydrase in cyanobacteria. J Bacteriol 179, 769-774.

Tripp, B. C., Smith, K. \& Ferry, J. G. (2001). Carbonic anhydrase: New insights for an ancient enzyme. J Biol Chem 276, 48615-48618.

Villarejo, A., Shutova, T., Moskvin, O., Forssen, M., Klimov, V. V. \& Samuelsson, G. (2002). A photosystem II-associated carbonic anhydrase regulates the efficiency of photosynthetic oxygen evolution. EMBO J 21, 1930-1938.

Weckesser, J. \& Jürgens, U. J. (1988). Cell walls and external layers. Methods Enzymol 167, 173-188.

Wilbur, K. M. \& Anderson, N. G. (1948). Electrometric and colorimetric determination of carbonic anhydrase. I Biol Chem 176, 147-154.

Yagawa, Y., Shiraiwa, Y. \& Miyachi, S. (1984). Carbonic anhydrase from the blue-green alga (cyanobacterium) Anabaena variabilis. Plant Cell Physiol 25, 775-783.

Zavarzin, G. A. (2002). Microbial geochemical calcium cycle. Mikrobiologiia 71, 1-17.

Zavarzin, G. A., Orleanskii, V. K., Gerasimenko, L. M., Pushko, S. N. \& Ushatinskaya, G. T. (2003). Laboratory simulations of cyanobacterial mats of the alkaline geochemical barrier. Mikrobiologiia 72, $80-85$.

Edited by: K. Forchhammer 